Western North American Naturalist 67(3), (C) 2007, pp. 368-377

\title{
ROADSIDE FORAGING BY KANGAROO RATS IN A GRAZED SHORT-GRASS PRAIRIE LANDSCAPE
}

\author{
Paul Stapp ${ }^{1,2}$ and Mark D. Lindquist ${ }^{2}$
}

\begin{abstract}
AвstRaCT.-We used live-trapping and foraging experiments to describe use of roadside vegetation by kangaroo rats (Dipodomys ordii) in short-grass prairie in Colorado, and to determine whether this species' perception of predation risk differed between roadside habitats, where predators were expected to be most active, and locations $120 \mathrm{~m}$ into adjacent grazed pastures. Giving-up densities (GUDs) were measured in paired seed trays placed beneath saltbush (Atriplex canescens) shrubs and in the open, $3 \mathrm{~m}$ from shrubs along transects in roadside and pasture locations. Trials were conducted on nights with a partial (1st-quarter), full, and new moon to assess how intensity of risk affected microhabitat use. Kangaroo rats were much more abundant in areas with saltbush cover than in grazed prairie, and were 4-6 times more numerous along roadsides in saltbush areas than in other locations. On dark nights and in pasture locations, foraging rates of kangaroo rats were similar in shrub trays and open trays. The fewest seeds were removed (i.e., GUDs were highest), however, in open trays along roads on moonlit nights, suggesting that kangaroo rats recognized potential risks associated with roadsides on bright nights. The high numbers of kangaroo rats along roads suggest that benefits associated with these habitats (ease of digging, dust bathing, higher soil seed banks) exceed the costs associated with higher risk of mortality from predators and vehicles. Our results demonstrate how foraging decisions differ depending on the spatial and temporal contexts in which behaviors are measured, and underscore the potential value of less common habitats such as road margins for increasing landscape-scale diversity and wildlife habitat in grazed grasslands.
\end{abstract}

Key words: Dipodomys ordii, giving-up density, landscape context, predation risk, roads.

The foraging behaviors of small mammals reflect trade-offs between locating and harvesting food efficiently, and minimizing exposure to predators (Lima and Dill 1990). Understanding the strategies employed by individual foragers may ultimately reveal mechanisms underlying patterns of local abundance (Bowers and Dooley 1993, Sutherland 1996, Smith and Litvaitis 2000). In northern short-grass prairie, Ord's kangaroo rats (Dipodomys ordii) are typically restricted to areas with sandy soils, large shrubs, and high plant diversity (Stapp et al. in press). They also are seen in high numbers, however, along unimproved gravel roads (Flake 1971, Abramsky 1978, Kaufman and Kaufman 1982), where vegetation and levels of disturbance differ markedly from the surrounding landscape, which is grazed by cattle. These granivorous rodents may be attracted to seeds produced by weedy plants growing in the ungrazed road margins (Betz 2001), or to the loose soils that facilitate dust bathing, burrow construction, and foraging (Brock and Kelt 2004). However, roads are also used extensively by carnivores such as coyotes (Canis latrans) and foxes (Vulpes velox; Roell 1999, Engeman et al. 2002, Kamler et al. 2003), and utility poles and fence posts that are associated with roads provide owls and raptors with an abundance of hunting perches (Marti 1974). Diets of Great Horned Owls (Bubo virginianus) in short-grass prairie suggest that they hunt along roadsides (Zimmerman et al. 1996); Ord's kangaroo rats comprised $16 \%-25 \%$ of the small rodents consumed by these owls. Foraging in the exposed areas of roads thus may be profitable, but also dangerous, especially on moonlit nights, when aboveground activity of rodents is more conspicuous (Kotler 1984, Longland and Price 1991).

If predation risk influences the surface activity of kangaroo rats, and ultimately, population density, individuals should concentrate foraging activities beneath large shrubs and other tall vegetation, and avoid exposed areas between shrubs. The difference in perceived risk between shrub and open microhabitats may contribute to this species' relative absence in upland areas of short-grass prairie (Stapp et al. in press), where the dominant vegetation is

1Department of Biological Science, California State University, Fullerton, CA 92831. E-mail: pstapp@fullerton.edu

${ }^{2}$ Shortgrass Steppe Long-Term Ecological Research Project, Department of Crop and Soil Sciences, Colorado State University, Fort Collins, CO 80523. 
very short $(<15 \mathrm{~cm})$. Dipodomys ordii is the only kangaroo rat found in grasslands of the Great Plains (Garrison and Best 1990), but it has never been captured in 10 years of livetrapping (nearly 30,000 trap-nights) in three 3.14-ha grassland sites in northern Colorado. It is among the most common rodents, however, in areas with shrub cover and sandier soils (Stapp et al. in press).

We used a combination of live-trapping and foraging trials in artificial seed trays to (1) investigate the use of roadside habitats by Ord's kangaroo rats in short-grass prairie and (2) evaluate the potential importance of predation risk as an explanation for the microhabitat affinities and local abundance patterns of kangaroo rats. We compared giving-up densities (GUDs; Brown 1988) in paired seed trays placed beneath the cover of shrubs and in the open on nights with different moonlight levels to determine the importance of predation risk as a determinant of microhabitat use. We compared foraging rates in seed trays along road margins with those from trays located far (120 $\mathrm{m}$ ) from the road into the adjacent pasture to determine if perceived predation risk differed by landscape position (roadside vs. pasture). If kangaroo rats behave so as to minimize predation risk, seed consumption should be higher (and GUDs lower) in shrub versus open microhabitats, in pasture versus roadside locations, and on dark versus moonlit nights.

\section{Methods}

The study area was the Central Plains Experimental Range (CPER), located in northern Colorado, $\left(40^{\circ} 49^{\prime} \mathrm{N}, 104^{\circ} 46^{\prime} \mathrm{W}\right)$. The climate at the CPER is semiarid, with cold, dry winters and most of the $322 \mathrm{~mm}$ of annual precipitation falling as rain between April and September (Lauenroth and Milchunas 1991). Vegetation was classified as short-grass prairie, and was dominated by 2 perennial warm-season grasses (Bouteloua gracilis and Buchloe dactyloides). Low-lying areas with loamy sand and sandy soils comprised a relatively small fraction $(<15 \%)$ of the study area, but often supported taller vegetation and a higher diversity of grasses, forbs, and woody shrubs such as four-wing saltbush (Atriplex canescens). The roads on the CPER were a mixture of dirt and gravel, and fine soil accumulated on the road margins as a result of regular grading. Vehicle traffic was very light, especially at night, when kangaroo rats were active. Because most pastures on the CPER were fenced, road margins were not grazed, except briefly when cattle were moved between pastures in late spring and autumn. Therefore vegetation along roadsides was much taller and cover was much greater than in the adjacent pastures (Betz 2001), and included native grasses (Pascopyron smithii, Sporobolus cryptandrus, and Stipa comata) and forbs (Helianthus annuus, Euphorbia glyptosperma, and Psoralidum tenuiflorum), as well as numerous exotic weeds (Eragrostis cilianensis, Kochia scoparia, Salsola iberica, Melilotus officinalis, and Verbena bracteata). Roadside habitats were largely maintained by cattle grazing and regular road grading; on open range in the nearby Pawnee National Grasslands, where there were no barbed-wire fences, vegetation along roads resembled that in the adjacent prairie.

Rodents were live-trapped on 3 occasions (30 September-3 October 1997, 20-23 April 1998, 17-24 August 1998) to estimate patterns of relative abundance along roadsides and in adjacent pastures. Pasture locations included upland grasslands, with short vegetation typical of short-grass prairie, and in mixed grassland-shrub areas dominated by saltbush (canopy cover $=3 \%-7 \%$; Stapp unpublished data). Most grasslands were grazed at a moderate stocking rate during summer, whereas saltbush areas were moderately grazed in winter. Trapping transects consisted of 12-15 large Sherman live-traps, set approximately $10 \mathrm{~m}$ apart. Transects were set out in pairs, with 1 along the road and the other approximately $120 \mathrm{~m}$ into the pasture. Transects were separated by $>100 \mathrm{~m}$. For each trapping session, traps were set for 4 consecutive nights and were checked each morning at dawn. Captured individuals were marked with aluminum ear tags and released. We used the number of unique individuals captured per 100 trap-nights as an index of relative abundance for each trapping session. Values were $\log (x+1)$-transformed for analysis. All procedures were approved by the Animal Care and Use Committee at Colorado State University and met guidelines recommended by the American Society of Mammalogists (1998).

Because kangaroo rats were absent from grassland pasture transects, foraging trials were 
conducted along roads and in pastures in saltbush areas only. Four 110-m transects were established along gravel roads, and 4 parallel transects were established approximately 120 $\mathrm{m}$ into the pastures. Foraging stations were approximately $20 \mathrm{~m}$ apart along each transect (3-4 stations per transect). At each station, cardboard seed trays $(40 \times 26.5 \times 5 \mathrm{~cm})$ were placed in pairs, with trays separated by $3 \mathrm{~m}$. One tray was placed beneath the canopy of a large saltbush and the other in open, short vegetation or bare soil, $\geq 3 \mathrm{~m}$ from any tall $(>0.25 \mathrm{~m})$ vegetation. Trays were placed near where kangaroo rats had been frequently livetrapped.

On each night of foraging trials, trays were supplied with $2 \mathrm{~L}$ of presifted, fine sand mixed with $4.00 \mathrm{~g}$ of millet. Millet was stored indoors in plastic film canisters, but was not ovendried before weighing. Foraging trials lasted 2-3 nights and were conducted on nights of a full, new, and 1st-quarter (hereafter, half) moon between 8 October and 4 November 1997. Seeds remaining in trays in the morning were sifted, cleaned of sand and debris, and weighed to estimate rates of seed consumption. The remaining seeds were dried at $55^{\circ} \mathrm{C}$ for 24 hours and reweighed to estimate and correct for moisture gained by seeds overnight. We also counted the number and kinds (morphotypes) of seeds that fell or blew into the trays from the surrounding vegetation as a rough index of seed rain during the study period. Relative humidity was measured at a standard weather station on the CPER on the morning following each trial. For 1 night for which weather data were not available, we estimated relative humidity from the average wet and dry bulb temperatures for the previous and subsequent night, using an equation provided by the U.S. Water Conservation Laboratory (Barnes 2005). Calculations using this equation tended to underestimate the measured values of relative humidity by $2.5 \%$.

Seed consumption values were used to calculate the giving-up density (GUD), the amount (g) of seeds left behind in each tray. Differences in GUDs between shrub and open trays reflect the animal's perception of the relative costs (e.g., predation risk, energetic costs, or missed-opportunity costs) and benefits (high harvest rates) of foraging in these microhabitats (Brown 1988). This technique has been widely used to study foraging behavior and microhabitat use of granivorous rodents, including several Dipodomys species (e.g., Brown 1988, Brown et al. 1988, Brown et al. 1994, Bouskila 1995, Herman and Valone 2000, Price and Correll 2001, Sullivan et al. 2001). In our study, only pairs of trays in which there was evidence of kangaroo-rat foraging (e.g., tail drags, large tracks) in at least 1 tray were included in GUD analyses (at $66 \mathrm{~g}, D$. ordii is about twice the size of other nocturnal rodents present). Pairs in which either tray had tracks or feces of other species (28 trays; primarily northern grasshopper mice, Onychomys leucogaster) were omitted. Because trays were always set out in pairs (1 open tray and 1 shrub tray), we analyzed the mean difference between GUDs in open and shrub trays at a given station. Foraging by other species resulted in large differences in sample sizes among moonlight levels and landscape locations; therefore, we used paired $t$ tests to determine whether mean differences in GUDs between shrub and open trays were significant in different locations during trials with different moonlight levels. SAS 9.0 was used for all statistical analyses. Means are presented with 1 standard error $\left(s_{\bar{x}}\right)$.

\section{RESUlTs}

Ord's kangaroo rat was the most commonly captured species (46\% of 124 individuals) and comprised $63 \%$ of the individuals captured in roadside transects and $19 \%$ of those in pasture transects. No kangaroo rats were captured in grassland pasture locations. The northern grasshopper mouse was the 2nd-most abundant species (30\% of individuals) and was captured primarily in pasture transects (89\% of captures). Deer mice (Peromyscus maniculatus; $21 \%$ of individuals) were much more common in road margins (81\% of captures) than in pastures. Two western harvest mice (Reithrodontomys megalotis) and 1 prairie vole (Microtus ochrogaster) were captured only in road margins, and a single hispid pocket mouse (Chaetodipus hispidus) was captured in a saltbush pasture site.

There was no significant difference in relative abundance of kangaroo rats between trapping sessions $\left(F_{2,33}=0.61, P=0.550\right)$, nor any significant interactions between trapping session and vegetation type (grassland, saltbush) or landscape location (roadside, pasture; 
$P>0.384)$ in a 3-way ANOVA. A 2-way ANOVA showed that kangaroo rats were more abundant along roadsides than in pastures in both vegetation types $(F=17.52$, df $=1, P=$ 0.0002 ), that they were more abundant in saltbush than in grasslands $(F=38.19$, df $=1, P$ $<0.0001$ ), and that they were 4-6 times more numerous along roads in saltbush areas than on other transects (interaction: $F=4.26$, $\mathrm{df}=$ 1, $P=0.047$; overall: $F_{3,32}=19.99, P<$ 0.0001; Fig. 1).

A total of 186 artificial seed trays were set out in 93 shrub-open pairs on 7 nights during the 3 lunar phases. Seeds in the trays gained an additional $0.8 \%-25 \%$ of their initial weight overnight, apparently by absorbing moisture from the air and sand (Fig. 2). The amount of water absorbed was significantly related to the amount of seeds remaining in the trays (Spearman's $r=0.94, P<0.001$ ); seeds in trays that were not visited increased more in weight $(14.0 \% \pm 0.9 \%$ of initial weight, $n=42)$, whereas seeds and chaff remaining in heavily foraged trays absorbed relatively little water (all foraged trays: $6.2 \% \pm 0.4 \%$ increase, $n=144$ ). The amount of weight gain was significantly related to relative humidity $(r=0.56, P<$ 0.001 ), with the greatest difference between wet and dry weights on nights with the highest humidity (Fig. 2). There was no significant difference in amount of weight gained between shrub and open trays $(t=1.17$, df $=$ 184, $P=0.244)$, regardless of whether trays were visited or not $(P>0.406)$.

There was no significant difference in the proportion of shrub and open trays foraged or not foraged in a given location during any session (Fig. 3A; Proc FREQ, separate chi-square tests for roadside and pasture locations in each session, $P>0.14$ ), except on roadsides during half-moon trials, when visitation was greater at shrub trays $\left(\chi^{2}=5.87, P=0.015\right)$. Pooling across all locations and microhabitats in a given session showed that kangaroo rats foraged in significantly more trays on new moon nights $(93.75 \%)$ than during either full-moon $(75.93 \%)$ or half-moon trials $(53.57 \% ; P<0.014)$.

We present results based on differences in dry-weight GUDs, although we obtained similar results when we repeated analyses using the wet-weight values and estimates of the amount of seed consumed, which were calculated by subtracting the wet-weight GUDs of

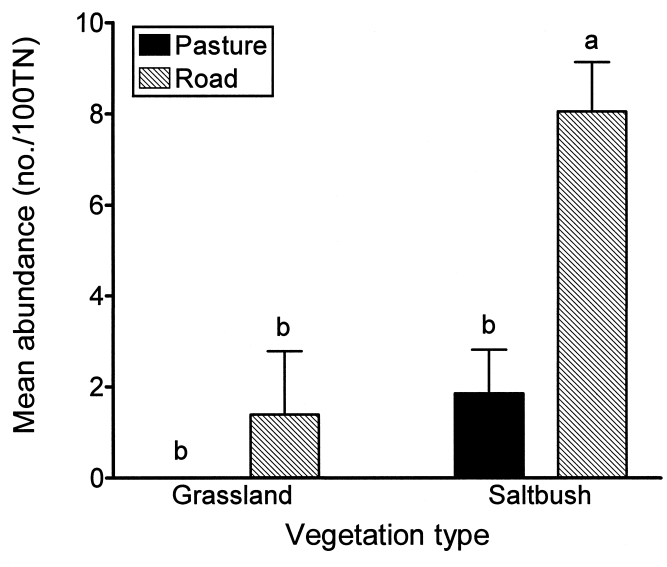

Fig. 1. Differences in relative abundance (number of unique individuals per 100 trap-nights) of kangaroo rats in road margins and $120 \mathrm{~m}$ into adjacent grassland and saltbush pastures. Values are means of captures from 3 transects in each location over three, 4-night trapping periods in 1997 and 1998. Bars with the same letters are not significantly different (2-way ANOVA with interaction: both main effects and interaction significant, $P<0.043)$.

trays that were visited from the mean GUD value of all unforaged trays on a given night. GUDs were significantly higher in open microhabitats than in shrub microhabitats, but only near roadsides on full $(t=2.75, P=0.018)$ and half-moon $(t=1.86, P=0.083)$ nights (Fig. 3B). There was no difference in GUDs between open and shrub trays near roads on dark nights $(t=1.06, P=0.308)$. Farther into the pastures, GUDs were similar between shrub and open trays during full-moon $(t=$ 1.01, $P=0.341)$ and new-moon $(t=0.61, P=$ $0.559)$ trials (Fig. 3B). On average, kangaroo rats foraged more in the open in pastures on halfmoon nights $(t=1.90, P=0.198)$, but sample size was low ( $n=3$ pairs). Results from nonparametric signed-ranks tests were similar, with differences between open and shrub trays significant only along roads on half- and full-moon nights $(P=0.021$ and 0.023 , respectively).

Deposition of wild seeds from the surrounding vegetation during foraging trials was higher in pasture trays and, especially, beneath shrubs (Fig. 4). Rates of seed fall were highest beneath shrubs in pasture trays, and lowest in open trays along the edge of the road (2-way ANOVA: $F_{3,8}=41.34, P<0.0001$; microhabitat, location, and interaction significant, $P<0.008$ ). Although seeds were only identified to morphospecies, the diversity of seed types was 


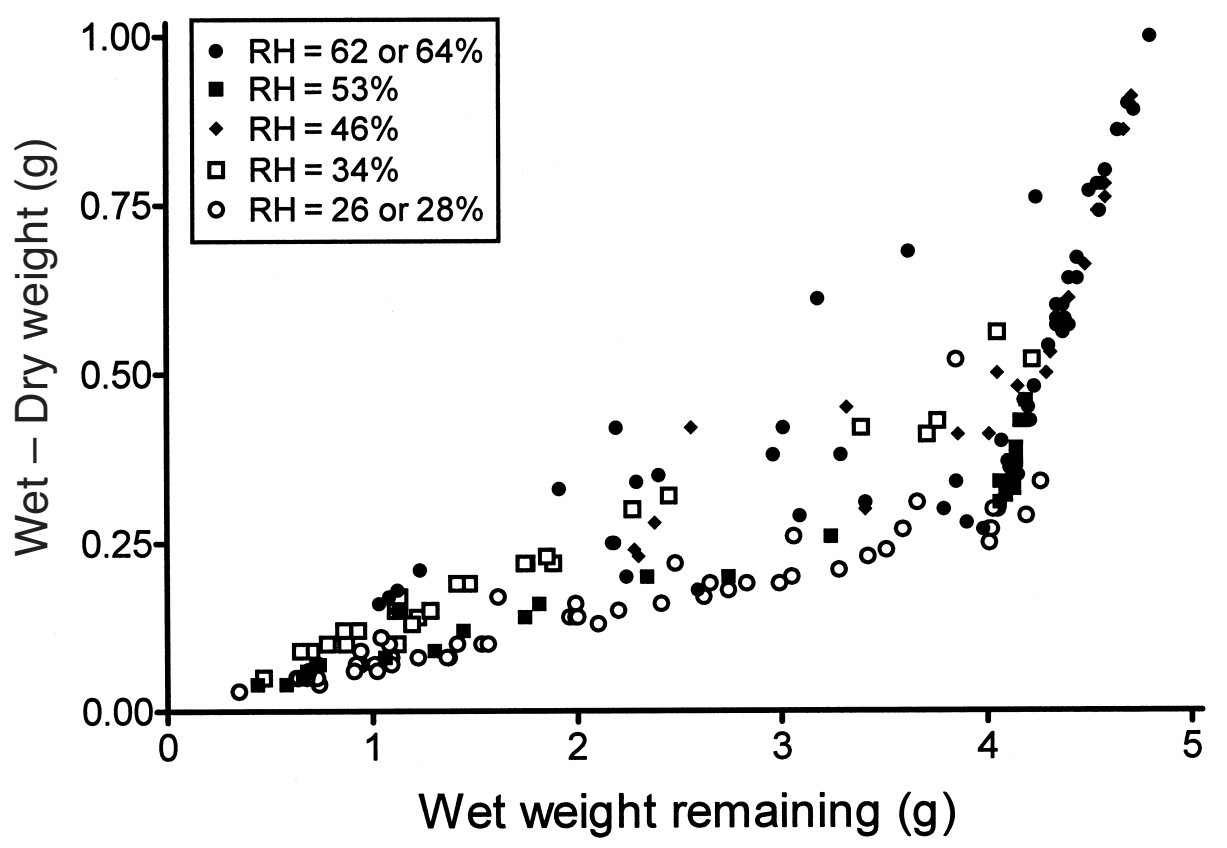

Fig. 2. Change in weight of seeds in seed trays as a function of final seed weight after foraging by kangaroo rats. Remaining seeds were dried at $55^{\circ} \mathrm{C}$ for 24 hours after being removed from trays (initial weight $4.0 \mathrm{~g}$ ). Relative humidity $(\mathrm{RH})$ was measured at a nearby weather station on the morning following each trial, except for 1 night when $\mathrm{RH}$ $(28 \%)$ was estimated from wet and dry bulb temperatures (see methods). Remaining wet weights $>4.0 \mathrm{~g}$ usually represented unforaged trays.

similar between microhabitats and locations $\left(F_{3,8}=0.33, P=0.802\right.$; overall mean $=1.56$ \pm 0.20 seed types $\cdot \mathrm{m}^{-2}$ night $^{-1}, n=12$ ).

\section{DisCUSSION}

From a methodological standpoint, we were surprised by the amount of water that seeds absorbed in foraging trays overnight, which was strongly related to relative humidity. In trays that were not visited or that were foraged only lightly, seeds gained much more weight than those in trays where few intact seeds remained, suggesting that the seeds, not the hulls, absorbed most of the moisture. Despite the potentially important implications for the use of GUDs in studies of granivore foraging behavior, to our knowledge this effect has not been quantified before. Kelt et al. (2004) adjusted seed removal rates for amount of moisture gained in an enclosed reference tray, but did not provide details on water gain. Absorption of water could lead to underestimates of seed consumption and overestimates of GUDs, particularly if relatively little seed is consumed, if the differences between GUDs in different microhabitats are small, or if data are pooled over multiple nights in areas where relative humidity varies greatly over time. Possible remedies include drying the remaining seeds before weighing (e.g., Morris and Davidson 2000), or using wet weights of seeds in trays that are not visited by rodents to correct GUDs for changes in water absorption. Others (Davidson and Morris 2001, Price and Correll 2001) have used changes in the number of seeds, as well as weight, to estimate GUDs, but this would increase processing time substantially. We obtained the same results whether we used dry or wet weights or whether we adjusted measures of seed consumption; however, we recommend drying seeds before and after foraging trials, especially if precise estimates of the amount of seed consumed are needed.

Ecological studies of roads have emphasized their negative effects, which include traffic noise, heavy metals pollution, vehicle mortality, and creation of barriers that fragment and isolate populations (Forman and Alexander 1998, Trombulak and Frissell 2000). In some systems, however, linear landscape features such 
A

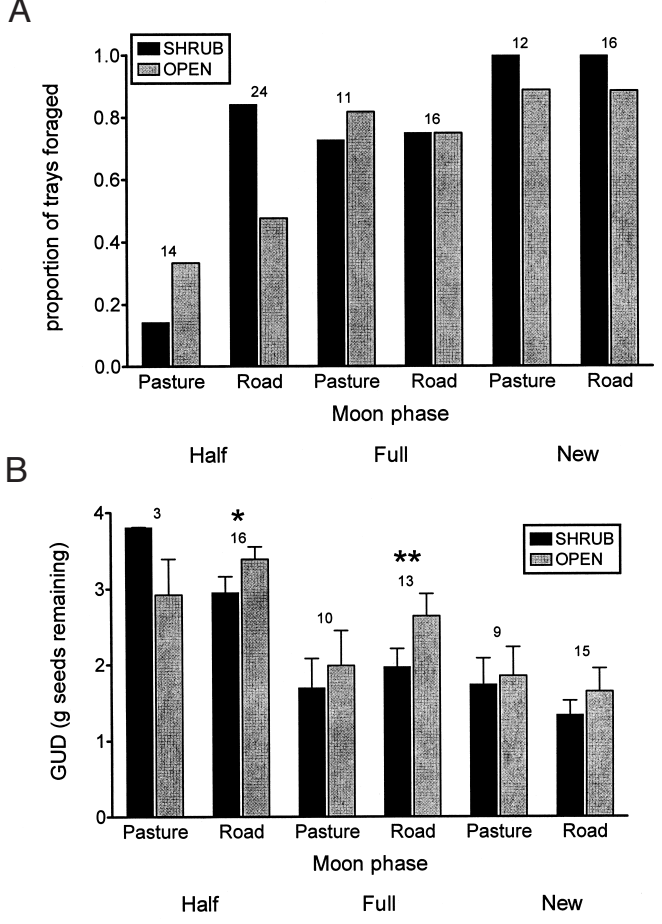

Fig. 3. Effects of moonlight and landscape location (roadside, pasture) on foraging behavior of kangaroo rats: (A) the proportion of trays placed beneath shrub and in open microhabitats that were foraged by kangaroo rats along roads and $120 \mathrm{~m}$ off the road (pasture) on nights with different moon phases; (B) mean giving-up densities (GUDs; $\pm 1 s_{\bar{x}}$ ) in shrub and open trays foraged by kangaroo rats in different landscape locations and under different moonlight conditions. Numbers over bars denote sample size (number of pairs of trays); asterisks indicate significant differences at $P \leq 0.10(*)$ and $P \leq 0.05$ (**) in $^{*}$ paired-sample $t$ tests.

as road margins may be important ecological features for small mammal populations. Road margins may be used as movement or dispersal corridors (Brock and Kelt 2004) and may provide opportunities for range expansion (Getz et al. 1978). Roadsides can also increase local diversity by providing habitats and resources that differ dramatically from the surrounding landscape (Adams and Geis 1983, Schwartz et al. 1994, Clark et al. 1996, Betz 2001). Finally, roadsides can serve as refugia when adjacent habitats are unsuitable (Bolger et al. 2001, Stapp et al. in press). The degree to which road margins function as corridors or suitable habitat, or act as sinks or ecological traps (Schlaepfer et al. 2002), varies among species and ecosystems.

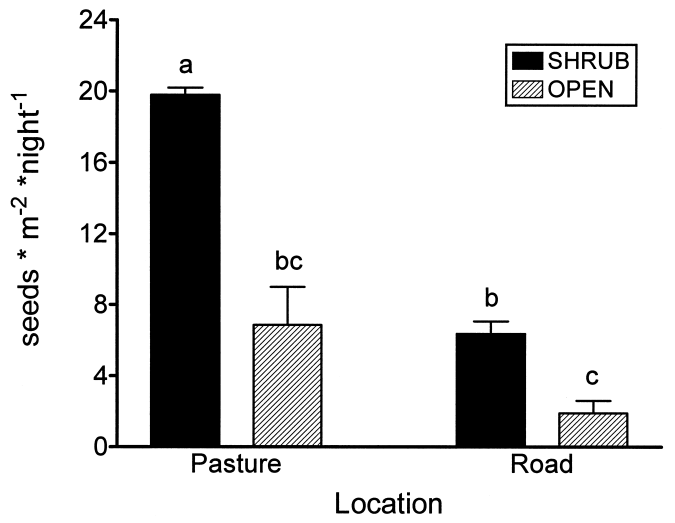

Fig. 4. Number of wild seeds falling into artificial trays during the 3 trials, expressed as the number of seeds per $\mathrm{m}^{2}$ of sand surface per night. Bars with the same letters are not significantly different (2-way ANOVA with interaction: both main effects and interaction significant, $P<$ 0.008).

In a structurally simple environment like short-grass prairie, vegetation associated with fenced roads contrasts markedly with the surrounding grazed grasslands that composed most of our study area. This contrast is less obvious in areas where the surrounding vegetation is taller and more productive, as was the case in the saltbush areas we studied. Ord's kangaroo rat was absent from grassland pastures, but a few individuals were able to live in the adjacent road margin, where grasses and forbs were taller (Betz 2001). More kangaroo rats were captured in saltbush pastures, where they were consistently the 2nd- or 3rdmost-common species (Stapp et al. in press), but the highest densities were found along roads in saltbush areas. Other species of Dipodomys are known to use roadsides and to reach high numbers there (Roberts and Packard 1973, Abramsky 1978, Price et al. 1994). Brock and Kelt (2004) captured similar numbers of D. stephensi along dirt roads and in sparse grasslands, but found fewer along gravel roads and in dense grasslands. They attributed the high rates of population turnover along roads to dispersal or possibly to high mortality associated with vehicles or predators.

Although we did not measure predation directly, our indirect measure of risk (differences in foraging activity between shrub and open microhabitats) suggested that kangaroo rats are sensitive to perceived predation risk, but that their response depends on both landscape 
context (pasture vs. roadside) and the expected degree of risk (moonlight intensity). In pasture locations and on dark nights, foraging rates of kangaroo rats were similar in shrub and open trays, which is consistent with the prevailing view that bipedal rodents such as kangaroo rats are able to use both open and shrub microhabitats (Reichman and Price 1991). The relatively low visitation rates during half-moon trials, which were conducted first, may indicate that individuals were slow to locate trays, especially in pasture transects where there were fewer kangaroo rats. Several studies have shown that kangaroo rats reduce their activity (Lockard and Owings 1974) and increase their use of bush microhabitats in response to increased illumination, presumably to reduce exposure to aerial predators (e.g., Schwab 1966, Kotler 1984, Price et al. 1984, Brown et al. 1988). Bouskila (1995) found that moonlight depressed foraging activity and increased use of shrubs by $D$. merriami and $D$. deserti, but only during autumn, when rattlesnakes were not active. Using spotlight counts, Kaufman and Kaufman (1982) showed that moonlight reduced overall activity and the use of roadside cover by kangaroo rats along gravel and dirt roads in tallgrass prairie in Kansas.

In contrast, we observed no increase in the use of shrubs on full-moon or partially illuminated nights in pasture locations; kangaroo rats instead significantly reduced their foraging activity in the open in roadside habitats in response to increased moonlight. Bowers and Dooley (1993) reported similar landscape-scale effects on foraging behavior in response to moonlight and cover. Increases in use of cover by Peromyscus leucopus and Microtus pennsylvanicus on moonlit nights were only detectable at grassland patch edges, which they attributed to higher activity and hunting success of predators in ecotones. Although we had no information on predator abundance or activity during our study, we speculate that $D$. ordii perceives the open roadside to be riskier on bright nights than on dark nights, at least during the autumn period when we conducted our study. Conspicuous activity in the open can attract predators and increase mortality. Attacks by Great Horned Owls on D. merriami were $\sim 40$ times higher in open microhabitats than in shrub microhabitats under full-moon nights, compared to $\sim 7$ times higher on newmoon nights (Longland and Price 1991). Daly et al. (1990) reported that predator mortality for radio-tagged D. merriami was highest for the most mobile animals, such as those that might be expected in roadside habitats if these habitats act as dispersal corridors.

If roadsides are riskier than adjacent pastures, why are kangaroo rats so abundant there? We cannot rule out the possibility that roadsides are population sinks or traps, such that density and habitat quality are decoupled (Van Horne 1983), although we captured primarily adults on roadsides ( $85 \%$ of total individuals captured vs. $37 \%$ in pastures), many of which were in breeding condition. Alternatively, rodents may simply be able to perform all necessary activities within the cover of vegetation, limiting their use of the open during brighter periods. Although seed rain was higher in shrub trays than in the open, it was much higher in the saltbush pasture than in the road margin. Our seed data are limited because they were collected only at night and over a very short time compared to the entire period of seed production, and because we did not distinguish between seeds that might be preferred or avoided by kangaroo rats. We also did not sample rodent caches or the soil seed bank. Price and Joyner (1997) found little correlation between seed rain and soil seed bank in the Mojave Desert, and suggested that granivores consume most of a year's seed crop before it enters the soil. Estimates of seed rain in their study $\left(262\right.$ seeds $\left.\cdot \mathrm{m}^{-2} \mathrm{~d}^{-1}\right)$ and during peak production in Arizona (215 seeds $\cdot \mathrm{m}^{-2} \mathrm{~d}^{-1}$; Pulliam and Brand 1975) were more than 1 order of magnitude higher than the highest values in our study $\left(19.8\right.$ seeds $\cdot \mathrm{m}^{-2}$ night $\left.^{-1}\right)$, but these authors measured seed rain continuously over periods of months.

Working at our study site, Betz (2001) found that soil seed densities, especially those of exotic plants, were significantly higher along roads than $25 \mathrm{~m}$ into pastures, which could explain why kangaroo rats forage intensively and reach high densities along roads. However, her study was conducted exclusively in and adjacent to grassland vegetation, where shrubs are rare, and where the plant communities are less productive and less diverse than in the saltbush areas where we worked. If our estimates of seed rain better reflect patterns of seed availability at microhabitat scales and in shrubdominated habitats, they might explain the tendency of kangaroo rats to forage beneath 
shrubs, but they cannot explain kangaroo rat abundance along roads. Our results are similar to those of Miller et al. (2003), who reported high densities of kangaroo rats in river bottoms, even though these areas were flooded seasonally and soil seed densities were much higher in upland habitats nearby. They suggested that the ease of digging in the sandy soils, combined with reduced competition from harvester ants, might explain high kangaroo rat densities in floodplains, despite the low seed densities and potential mortality from flooding. In our study, predation risk and, therefore, mortality may be greater along roadsides, but the benefits associated with these habitats apparently outweigh the costs.

There is increasing demand to manage western rangelands for values other than livestock production, including wildlife (Vavra 2005). Although disturbances associated with roadsides may facilitate invasion by exotic plant species (e.g., Forcella and Harvey 1983, Greenberg et al. 1997), the strong contrast between vegetation in road margins and the adjacent grazed pastures in short-grass prairie contributes to biodiversity at a landscape scale. Our results suggest that vegetation along rural roads with low vehicle traffic provides habitat for small mammals that are less common, such as Ord's kangaroo rats, in locations where the natural prairie vegetation, under levels of grazing considered typical for the region, would not normally allow them to persist. In our study, the relative value of road margins as habitat for small mammals seemed to depend on vegetation in the surrounding pastures; that is, roadside vegetation in more productive, saltbush-dominated areas was, qualitatively, more similar to adjacent pastures, and relative numbers of kangaroo rats were, as a result, similar as well. As suggested by the differences in perceived risk by kangaroo rats between open and shrub microhabitats on moonlit nights, roadsides may also be important foraging habitats for vertebrate carnivores, including species of regional conservation concern such as the swift fox and Burrowing Owl (e.g., Haug and Oliphant 1990, Kintigh and Andersen 2005). Efforts to maintain and increase landscapescale heterogeneity in grazed grasslands, as well as in areas with other agricultural lands (e.g., Saarinen et al. 2005), should include lesscommon landscape elements such as roadsides and fence rows to enhance local biodiversity.

\section{ACKNOWLEDGMENTS}

Logistical support was provided by the Shortgrass Steppe Long-term Ecological Research Project (DEB-9632852) at Colorado State University. We thank the USDA Agricultural Research Service for allowing us to conduct research on the CPER, and J. Roach, D. Smith, L. Clippard, and J. Lindquist for their help with field work. Comments by M. Price and 3 anonymous reviewers greatly improved the manuscript.

\section{Literature Cited}

Aвramsky, Z. 1978. Small mammal community ecology: changes in species diversity in response to manipulated productivity. Oecologia 34:113-123.

Adams, L.W., AND A.D. GeIs. 1983. Effects of roads on small mammals. Journal of Applied Ecology 20: 403-415.

American Society of Mammalogists. 1998. Guidelines for the capture, handling, and care of mammals as approved by the American Society of Mammalogists. Journal of Mammalogy 79:1416-1431.

BARNES, E. 2005. Relative humidity: an important environmental measurement [online]. U.S. Water Conservation Laboratory [cited 30 January 2005]. Available from: http://www.uswcl.ars.ag.gov/exper/relhumeq .htm

BetZ, D. 2001. Dynamics of exotic species in the Pawnee National Grasslands, CO, USA. Master's thesis, Colorado State University, Fort Collins.

Bolger, D.T., T.A. ScotT, And J.T. Rotenberry. 2001. Use of corridor-like landscape structures by bird and small mammal species. Biological Conservation 102: 213-224.

BouskiLA, A. 1995. Interactions between predation risk and competition: a field study of kangaroo rats and snakes. Ecology 76:165-178.

Bowers, M.A., AND J.L. Dooley, JR. 1993. Predation hazard and seed removal by small mammals: microhabitat versus patch scale effects. Oecologia 94:247-254.

BRock, R.E., AND D.A. KELT. 2004. Influence of roads on the endangered Stephen's kangaroo rat (Dipodomys stephensi): are gravel and dirt roads different? Biological Conservation 118:633-640.

Brown, J.S. 1988. Patch use as an indicator of habitat preference, predation risk and competition. Behavioral Ecology and Sociobiology 22:37-47.

Brown, J.S., B.P. Kotler, R.J. SMith, and W.O. Wirtz, III. 1988. The effects of owl predation on the foraging behavior of heteromyid rodents. Oecologia 76: 408-415.

Brown, J.S., B.P. Kotler, AND T.J. Valone. 1994. Foraging under predation: a comparison of energetic and predation costs in rodent communities in the Negev and Sonoran Deserts. Australian Journal of Zoology 42:435-448.

Clark, B.K., B.S. Clark, W.E. Munsterman, and T.R. Homerding. 1996. Differential use of roadside fencerows and contiguous pastures by small mammals in 
southeastern Oklahoma. Southwestern Naturalist 41: $54-59$.

Daly, M., M. Wilson, P.R. Behrends, and L.F. Jacobs. 1990. Characteristics of kangaroo rats, Dipodomys merriami, associated with differential predation risk. Animal Behaviour 40:380-389.

Davidson, D.L., AND D.W. Morris. 2001. Density-dependent foraging effort of deer mice (Peromyscus maniculatus). Functional Ecology 15:575-583.

Engeman, R.M., M.J. Pipas, K.S. Gruver, J. Bourassa, AND L. Allen. 2002. Plot placement when using a passive tracking index to simultaneously monitor multiple species of animals. Wildlife Research 29: 85-90.

FLAKE, L.D. 1971. An ecological study of rodents in a shortgrass prairie in northeastern Colorado. U.S. International Biological Programme, Grassland Biome Technical Report No. 100, Fort Collins, CO. 92 pp.

ForCELla, F., and S.J. HaRvey. 1983. Eurasian weed infestation in western Montana in relation to vegetation and disturbance. Madroño 30:102-109.

Forman, R.T.T., AND L.E. Alexander. 1998. Roads and their major ecological effects. Annual Review of Ecology and Systematics 29:207-231.

Garrison, T.E., and T.L. Best. 1990. Dipodomys ordii. Mammalian Species 353:1-10.

GetZ, L.L., F.R. Cole, AND D.L. Gates. 1978. Interstate roadsides as dispersal routes for Microtus pennsylvanicus. Journal of Mammalogy 59:208-212.

Greenberg, C.H., S.H. Crownover, and D.R. Gordon. 1997. Roadside soils: a corridor for invasion of xeric scrub by nonindigenous plants. Natural Areas Journal 17:99-109.

HaUG, E.A., AND L.W. Oliphant 1990. Movements, activity patterns and habitat use of Burrowing Owls in Saskatchewan. Journal of Wildlife Management 54: $27-35$.

Herman, C.S., and T.J. Valone. 2000. The effect of mammalian predator scent on the foraging behavior of Dipodomys merriami. Oikos 91:139-145.

Kamler, J.F., W.B. Ballard, E.B. Fish, P.R. Lemons, K. Mote, and C.C. Perchellet. 2003. Habitat use, home ranges and survival of swift foxes in a fragmented landscape: conservation implications. Journal of Mammalogy 84:989-995.

Kaufman, D.W., and G.A. Kaufman. 1982. Effect of moonlight on activity and microhabitat use by Ord's kangaroo rat (Dipodomys ordii). Journal of Mammalogy 63:309-312.

Kelt, D.A., P.L. Meserve, M.L. Forister, L.K. Nabors, AND J.R. GUTIÉRREZ. 2004. Seed predation by birds and small mammals in semiarid Chile. Oikos 104: 133-141.

Kintigh, K.M., And M.C. Andersen. 2005. A den-centered analysis of swift fox (Vulpes velox) habitat characteristics in northeastern New Mexico. American Midland Naturalist 154:229-239.

KotLER, B.P. 1984. Risk of predation and the structure of desert rodent communities. Ecology 65:689-701.

LauenRoth, W.K., AND D.G. Milchunas. 1991. Short-grass steppe. Pages 183-226 in R.T. Coupland, editor, Natural grasslands: introduction and Western Hemisphere. Ecosystems of the World 8A. Elsevier, New York.

Lima, S.L., AND L.M. Dill. 1990. Behavioral decisions made under the risk of predation: a review and prospectus. Canadian Journal of Zoology 68:619640.

Lockard, R.B., and D.H. Owings. 1974. Moon-related surface activity of bannertail (Dipodomys spectabilis) and Fresno (D. nitratoides) kangaroo rats. Animal Behaviour 22:262-273.

Longland, W.S., And M.V. Price. 1991. Direct observations of owls and heteromyid rodents: can predation risk explain microhabitat use? Ecology 72:2261-2273.

MarTI, C.D. 1974. Feeding ecology of four sympatric owls. Condor 76:45-51.

Miller, M.S., K.R. Wilson, and D.C. Andersen. 2003. Ord's kangaroo rats living in floodplain habitats: factors contributing to habitat attraction. Southwestern Naturalist 48:411-418.

Morris, D.W., AND D.L. DAvidSOn. 2000. Optimally foraging mice match patch use with habitat differences in fitness. Ecology 81:2061-2066.

Price, M.V., and R.A. CorReLl. 2001. Depletion of seed patches by Merriam's kangaroo rats: are GUD assumptions met? Ecology Letters 4:334-343.

Price, M.V., And J.W. Joyner. 1997. What resources are available to desert granivores: seed rain or soil seed bank? Ecology 78:764-773.

Price, M.V., P.A. Kelly, and R.L. Goldingay. 1994. Distances moved by Stephen's kangaroo rat (Dipodomys stephensi Merriam) and implications for conservation. Journal of Mammalogy 75:929-939.

Price, M.V., N.M. Waser, and T.A. Bass. 1984. Effects of moonlight on microhabitat use by desert rodents. Journal of Mammalogy 65:353-356.

Pulliam, H.R., AND M.R. BRAND. 1975. The production and utilization of seeds in plains grasslands of southeastern Arizona. Ecology 56:1158-1166.

Reichman, O.J., And M.V. Price. 1991. Ecological aspects of heteromyid foraging. Pages 539-574 in H.H. Genoways and J.H. Brown, editors, Biology of the Heteromyidae. Special Publication No. 10. American Society of Mammalogists.

Roberts, J.D., and R.L. Packard. 1973. Comments on movement, home range and ecology of the Texas kangaroo rat, Dipodomys elator. Journal of Mammalogy 54:957-962.

Roell, B.J. 1999. Population ecology and home range of the swift fox (Vulpes velox) in northeastern Colorado. Master's thesis, University of Northern Colorado, Greeley.

Saarinen, K., A. Valtonen, J. Jantunen, and S. Saarnio. Butterflies and diurnal moths along road verges: does road type affect diversity and abundance? Biological Conservation 123:403-412.

Schlaepfer, M.A., M.C. Runge, And P.W. Sherman. 2002. Ecological and evolutionary traps. Trends in Ecology and Evolution 17:474-480.

SCHWAB, R.G. 1966. Environmental factors affecting surface activity of the kangaroo rat (Dipodomys merriami). Doctoral dissertation, University of Arizona, Tucson.

Schwartz, O.A., A.M. Vivas, A. OrRis, and C.J. Miller. 1994. Small mammal species associations in three types of roadside habitats in Iowa. Prairie Naturalist 26:45-52.

Smith, D.F., AND J.A. Litvaitis. 2000. Foraging strategies of sympatric lagomorphs: implications for differential success in fragmented landscapes. Canadian Journal of Zoology 78:2134-2141. 
Stapp, P., M.D. Lindquist, and B. Van Horne. In press. Mammals of shortgrass steppe. In: W.K. Lauenroth and I.C. Burke, editors, Ecology of shortgrass steppe: perspectives from long-term studies. Oxford University Press, New York.

Sullivan, H.L, C.G. Curtin, C.A. Reynolds, and S.G. CARDIFF. 2001. The effect of topography on the foraging costs of heteromyid rodents. Journal of Arid Environments 48:255-266.

Sutherland, W.J. 1996. From individual behaviour to population ecology. Oxford University Press, Oxford, U.K. 202 pp.

Trombulak, S.C., AND C.A. Frissell. 2000. Review of ecological effects of roads on terrestrial and aquatic communities. Conservation Biology 14:18-30.
VAn Horne, B. 1983. Density as a misleading indicator of habitat quality. Journal of Wildlife Management 47: 893-901.

VAVRA, M. 2005. Livestock grazing and wildlife: developing compatibilities. Rangeland Ecology and Management 58:128-134.

Zimmerman, G., P. Stapp, and B. Van Horne. 1996. Seasonal variation in the diet of Great Horned Owls (Bubo virginianus) on shortgrass prairie. American Midland Naturalist 136:149-156.

Received 19 June 2006 Accepted 26 January 2007 